\title{
Título da página electrónica: Women Waging Peace
}

Endereço: http://www.womenwagingpeace.net

\section{Tatiana Moura}

\section{(2) OpenEdition \\ Journals}

Edição electrónica

URL: http://journals.openedition.org/rccs/1097

DOI: $10.4000 /$ rccs. 1097

ISSN: 2182-7435

\section{Editora}

Centro de Estudos Sociais da Universidade de Coimbra

Edição impressa

Data de publição: 1 junho 2004

Paginação: 177-178

ISSN: 0254-1106

Refêrencia eletrónica

Tatiana Moura, «Título da página electrónica: Women Waging Peace», Revista Crítica de Ciências

Sociais [Online], 68 | 2004, posto online no dia 01 outubro 2012, consultado o 22 setembro 2020. URL http://journals.openedition.org/rccs/1097 ; DOI : https://doi.org/10.4000/rccs.1097 


\section{Espaço Virtual}

\section{Título da página electrónica: International Committee of the Red Cross (ICRC) - Women and War Section \\ Endereço:http://www.icrc.org/Web/eng/siteengo.nsf/iwpList2/Focus: Women_and_War}

O Comité Internacional da Cruz Vermelha (CICV) tem como objectivo e grande responsabilidade a protecção e promoção do respeito pelo direito internacional humanitário em tempos de guerra. As mulheres constituem um colectivo particularmente afectado e vulnerável em situações de conflitos armados, apesar da ampla protecção outorgada pelo direito internacional humanitário. Neste sentido, o CICV criou a secção "Mulheres e Guerras", dedicada à análise dos múltiplos papéis assumidos por mulheres em tempos de guerra e aos impactos sofridos pelas mulheres em distintas situações de conflitos armados, em grande medida provocados pelo desrespeito de normas internacionais de protecção humanitária. Esta secção contém publicações do CICV, estudos e documentos sobre a participação de mulheres em contextos de guerra, um observatório de imprensa com artigos relacionados com esta temática, bem como sugestões de outros endereços electrónicos relevantes. A visibilidade e o maior conhecimento sobre a participação das mulheres em conflitos armados são os princípios que pautam a actuação da organização, através de estudos e de projectos específicos. Estes estudos e projectos centram-se na análise dos impactos específicos das guerras nas vidas das mulheres, nomeadamente enquanto vítimas de violência sexual, prisioneiras de guerra, refugiadas e deslocadas, tendo em consideração a especificidade de cada conflito armado. Os casos analisados passam pelo Afeganistão, Burundi, Eritreia, Colômbia, entre outros.

\section{Título da página electrónica: Women Waging Peace Endereço: http://www.womenwagingpeace.net}

O programa Women Waging Peace, uma iniciativa do Hunt Alternatives Fund lançada em 1999 com uma duração de seis anos, tem como principal objectivo promover a plena participação de mulheres em processos de paz formais e informais em todo o mundo. Para tal, esta rede reúne mulheres provenientes de diferentes áreas do mundo que vivem situações de conflito armado com o intuito de partilharem estratégias de consolidação da paz e de moldarem políticas públicas. Esta rede conta actualmente com cerca de 200 especialis- tas com distintos backgrounds (como membros de governos, directoras de organizações não governamentais, advogadas, professoras, jornalistas, entre outras) que contribuem com investigações e análises sobre as actividades de mulheres na prevenção de conflitos, negociação e reconstrução pós-bélica em quinze situações de conflito armado. Estes estudos têm como finalidade o desenho de propostas alternativas que pretendem moldar programas oficiais e influenciar políticas públicas. 
Women Waging Peace é também membro do Women, Peace and Security Web Ring, um projecto da Women's International League for Peace and Freedom, que tem como objectivo acompanhar a implementação da Resolução 1325 do Conselho de Segurança das Nações Unidas sobre mulheres, paz, segurança e direitos humanos. Neste site podemos aceder a inúmeros es- tudos sobre a participação de mulheres na prevenção de conflitos, em negociações de paz e nos processos de reconstrução pós-conflito que decorrem em várias regiões (África, Américas, Ásia, Europa e Médio Oriente), bem como às publicações $\mathrm{da}$ rede, a documentos de política internacional e a uma base de dados bibliográfica sobre o tema.

\section{Título da página electrónica: UNIFEM's Portal on Women, Peace \& Security Endereço: http://www.womenwarpeace.org}

O UNIFEM's Portal on Women, Peace and Security foi recentemente lançado pelo United Nations Development Fund for Women (UNIFEM) e constitui uma das medidas adoptadas para a implementação da Resolução 1325/2000 do Conselho de Segurança das Nações Unidas sobre Mulheres, Paz e Segurança, em particular no que diz respeito à necessidade de reunir e disponibilizar dados sobre os impactos de conflitos armados nas vidas de meninas e mulheres.

Segundo Noeleen Heyzer, Directora Executiva da UNIFEM, as mulheres em todo o mundo vivem as guerras de forma distinta. No entanto, muitos dos problemas e necessidades são comuns. Esta página fornece análises sobre questões que afectam de forma particular as mulheres, durante e após os conflitos armados. Entre elas podemos destacar o problema das minas antipessoais, do tráfico, da violência, ou as operações de manutenção da paz e de reconstrução pós-conflito.
As informações reunidas e disponibilizadas neste site pretendem colmatar em grande medida a falta de sistematização de dados e análises existentes sobre as experiências vividas por mulheres durante e após os conflitos armados, bem como sobre a sua participação na construção da paz. A informação sistematizada nesta página provém de diversas fontes (como o Conselho de Segurança e a Assembleia Geral das Nações Unidas, o Alto Comissariado das Nações Unidas para os Direitos Humanos, a UNICEF, entre outras), com links para relatórios e dados do sistema das Nações Unidas, de académicos, organizações não governamentais (ONG) e artigos de imprensa.

Através desta página, podemos também aceder a páginas electrónicas de ONGs internacionais que trabalham sobre esta temática e a revistas como o Journal of Women's Studies e o Journal of Conflict Resolution, entre outros.

Tatiana Moura 